\title{
IMPLEMENTASI PINJAMAN TUNDA TEBANG HUTAN RAKYAT DI KABUPATEN BLORA DAN KABUPATEN WONOSOBO, PROVINSI JAWA TENGAH
}

\author{
(Implementation of Loan for Delaying Timber Harvesting for Private Forest \\ in Blora Regency and Wonosobo Regencies, Central Java Province)
}

\author{
Duhita Herlyn Lusiya $^{1}$, Dudung Darusman ${ }^{2}, \&$ Nunung Nuryartono ${ }^{3}$ \\ ${ }^{1}$ Program Studi Pengelolaan Sumberdaya Alam dan Lingkungan, Fakultas Multidisplin, \\ Institut Pertanian Bogor, Jl. Padjajaran, Baranangsiang, Bogor 16144, Indonesia; \\ E-mail: duhita.lusiya@yahoo.com \\ ${ }^{2}$ Departemen Manajemen Hutan, Fakultas Kehutanan, Institut Pertanian Bogor, Jl. Lingkar Akademik, Kampus \\ IPB Dramaga, Bogor 16680, Indonesia; E-mail: dudungdarusman@gmail.com \\ ${ }^{3}$ Departemen Ekonomi, Fakultas Ekonomi dan Manajemen, Institut Pertanian Bogor, Jl. Agatis, Kampus IPB \\ Dramaga, Bogor 16680, Indonesia; E-mail: nnuryar@gmail.comd
}

Diterima 23 Oktober 2017, direvisi 27 Juli 2020, disetujui 27 Juli 2020

\begin{abstract}
Loan for delaying timber harvesting known as Pinjaman Tunda Tebang (PTT) launched by the government to help forest farmer in order to fulfill their needs. This program is designed to delay the harvesting of young trees till can reach the cycle age for optimum sustainability and economic value. The study aims to determine farmer's understanding and loan implementation based on PTT principle in Blora and Wonosobo Regencies by using quantitative approach and descriptive statistics analysis. Data collection was carried out through interviews and questionnaires to 222 respondents. The results showed that understanding of the debtor farmers are among others: the loan process is complicated and time-consuming, lack of commitment to the contract, useful loan, and satisfy with loan mechanism compared to middlemen. Implementation of PTT related to the "appropriate subject" and "appropriate location" is in accordance with the provisions. However, there is still disobedience to some commitments, such as "appropriate activity" commitment by harvesting the collateral tree before the contract ended, non-smooth repayment of loans by some farmers on the "appropriate disbursement and repayment" commitment. The study recommends: a) bureaucratic and procedural mechanisms improvement to accelerate the process, precise, and useful; b) improvement of rules or procedures related the harvesting due to force majeure such as pest and disease attack and its protection, field assistants, as well as field technical guidance, especially the resilience of tree label.
\end{abstract}

Keywords: Private forest; farmer commitment; loan for delaying timber harvesting; principle of loan.

\begin{abstract}
ABSTRAK
Pinjaman Tunda Tebang (PTT) telah diluncurkan oleh Pemerintah untuk membantu petani hutan rakyat dalam memenuhi kebutuhannya. Esensi program ini untuk menunda tebang pohon berumur muda sehingga mencapai umur daur untuk kelestarian dan nilai ekonomi yang optimal. Penelitian bertujuan menjelaskan pemahaman petani terhadap PTT dan bagaimana implementasinya berdasarkan prinsip PTT di Kabupaten Blora dan Wonosobo. Pendekatan yang digunakan adalah metode kuantitatif dan analisis statistik deskriptif. Pengumpulan data dilakukan melalui wawancara terhadap 222 responden. Hasil penelitian menunjukkan bahwa pemahaman petani debitur antara lain proses pinjaman rumit dan membutuhkan waktu lama, kurangnya komitmen terhadap kontrak, manfaat pinjaman bernilai positif, dan puas dengan mekanisme pinjaman dibanding tengkulak. Implementasi PTT terkait Tepat Pelaku dan Tepat Lokasi sudah sesuai ketentuan. Masih ada ketidak-taatan komitmen pada Tepat Kegiatan dengan menebang pohon agunan sebelum jatuh tempo dan ketidak-lancaran pengembalian pinjaman beberapa petani pada Tepat Penyaluran dan Pengembalian. Rekomendasi: a) perlu perbaikan mekanisme birokrasi dan prosedural yang cepat, tepat, dan bermanfaat; b) penyempurnaan aturan atau prosedur pinjaman terkait tebangan
\end{abstract}


yang bersifat force majeur seperti serangan hama penyakit dan aksi penyelamatannya, SDM pendamping lapangan, dan petunjuk teknis lapangan khususnya penanda pohon yang mudah dipelihara, tahan lama, dan tidak mudah hilang/rusak.

Kata kunci: Hutan rakyat; komitmen petani; pinjaman tunda tebang; prinsip pinjaman.

\section{PENDAHULUAN}

Hutan rakyat berpotensi untuk memenuhi kebutuhan bahan baku kayu industri primer. Selain itu, hutan rakyat juga memiliki manfaat sebagai penyimpankarbon(Klooster \& Masera, 2000; Huang \& Kronrad, 2001; Purwanto, Maryudi, Yuwono, Permadi, \& Sanjaya, 2015), meningkatkan pendapatan petani (Darusman \& Hardjanto, 2006; Awang et al., 2001), konservasi tanah dan air, mengurangi bahaya banjir dan longsor, dan menyerap tenaga kerja (Kozak, 2007; Antinori \& Bray, 2005). Produksi kayu dari HR terus mengalami peningkatan dalam periode 2011-2013, berturut-turut sebesar 2,8 juta $\mathrm{m}^{3} /$ tahun, 3,2 juta $\mathrm{m}^{3} /$ tahun, dan 7,01 juta $\mathrm{m}^{3} /$ tahun (Kementerian Kehutanan, 2012; Kementerian Kehutanan, 2013; KLHK, 2014). Kayu dari HR juga menyumbang pasokan sekitar 70-90\% untuk memenuhi kebutuhan bahan baku kayu pertukangan dan kayu bakar di Pulau Jawa (Hardjanto, 2006).

Walaupun perkembangan hutan rakyat cukup meningkat tetapi petani menghadapi sejumlah tantangan dalam pengelolaannya. Selaku pemilik lahan, petani mempunyai kebutuhan finansial untuk memenuhi kebutuhan hidupnya, baik yang bersifat mendesak maupun tidak mendesak. Kebutuhan finansial yang diharapkan dapat meningkatkan ekonomi masa depan saat ditebang sesuai daur, pada kenyataanya tidak tercapai. Petani menebang pohonnya pada umur tegakan masih sangat muda atau memiliki diameter kecil. Hutan rakyat bagi petani menjadi tabungan yang dipergunakan sewaktu-waktu untuk memenuhi kebutuhan mendesak petani (Awang et al., 2001; Rohadi et al., 2012; Puspitojati, Mile, Fauziah, \& Darusman, 2014). Kebutuhan mendesak biasanya berkaitan dengan biaya pernikahan, pengobatan, sekolah, pembangunan rumah, dan perayaan hari raya (Nugroho, 2010; Dharmawan, Mardiyaningsih, \& Wianti, 2012; Nugroho, Soedomo, \& Dermawan, 2017).

Aktivitas petani yang menebang pohon tidak sesuai daur dikenal sebagai tebang butuh. Penebangan kayu yang tidak sesuai daur berdampak pada volume produksi menjadi lebih kecil, nilai optimal ekonomi kayu tidak tercapai, berkurangnya investasi tegakan (Darusman \& Hardjanto, 2006; Suprapto, 2010) dan kontinuitas pendapatan menurun (Mustari, 2000).

Pilihan kebijakan pemerintah dalam memberi bantuan untuk memenuhi kebutuhan mendesak petani perlu mendapat apresiasi dengan adanya program Pinjaman Tunda Tebang (PTT). PTT merupakan program dana bergulir yang diluncurkan oleh Badan Layanan Umum Pusat Pembiayaan Pembangunan Hutan, Kementerian Lingkungan Hidup dan Kehutanan, selanjutnya disebut BLU, dengan tujuan menunda tebang pohon sehingga mencapai umur daur untuk kelestarian dan mencapai nilai ekonomi yang optimal. Pemberian PTT pada hutan rakyat dapat dikategorikan sebagai micro small credit untuk pengentasan kemiskinan (Qureshi et al., 2012; Nugroho, Dermawan, \& Putzel, 2013; Yergin, Mercan, \& Erol, 2015) sebagaimana tertuang dalam Peraturan Menteri Lingkungan Hidup dan Kehutanan No. P.59/Menlhk-Setjen/2015 tentang Tata Cara Penyaluran dan Pengembalian Dana 
Bergulir untuk Kegiatan Rehabilitasi Hutan dan Lahan jo. Peraturan Menteri Kehutanan No. P.36/Menhut-II/2012.

Proses PTT yang dilakukan di Kabupaten Wonosobo pada tahun 2012 menunjukkan bahwa penebangan pohon yang telah diagunkan dan pemilik pohon sudah mendapat pinjaman tunda tebang, dilakukan dengan alasan diserang hama dan penyakit. Terkait hal ini maka komitmen petani untuk menjaga dan memelihara pohon agunan sangat diperlukan. Komitmen petani perlu untuk mengetahui produksi akhir panen atau keuntungan dari pinjaman tunda tebang. Nugroho et al. (2017) menyatakan bahwa di Kabupaten Blora dan Wonosobo, implementasi pinjaman tunda tebang berjalan sesuai prosedur yang telah ditetapkan. Namun demikian, penelitian tersebut dilakukan ketika program dijalankan hanya dalam waktu satu tahun.

Kajian ilmiah terhadap implementasi PTT penting dilakukan untuk menjamin capaian tujuan dari program peningkatan produksi hutan tanaman rakyat, khususnya yang sudah berjalan selama tiga tahun di Kabupaten Blora dan Wonosobo. Tujuan penelitian adalah untuk mengkaji komitmen petani dengan diberikannya PTT, mengkaji implementasi prinsip-prinsip pinjaman oleh petani, serta mengetahui dan mengidentifikasi perilaku petani dalam memanfaatkan uang PTT yang dijelaskan secara deskriptif.

\section{METODE PENELITIAN}

Kebutuhan pasokan kayu untuk industri kehutanan diharapkan dapat juga diperoleh dari hutan rakyat. Teori social forestry menjelaskan bahwa pengelolaan hutan dilakukan bersama dengan masyarakat, baik di hutan negara maupun di hutan rakyat. Pengelolaan hutan rakyat melalui PTT diharapkan dapat meningkatkan pendapatan masyarakat yang mengambil manfaat dari hutan miliknya. Problem utama peningkatan pendapatan tersebut adalah pendanaan yang belum ada, terutama bantuan dari pemerintah.

Dove (1995) menjelaskan peningkatan pendapatan perlu didukung peran pemerintah dalam bentuk subsidi atau pinjaman. Pendanaan sedapat mungkin sesuai dengan prinsip-prinsip pemberian pendanaan, baik berupa pinjaman tanpa bunga maupun subsidi (Kant \& Appanah, 2013). Prinsip 4T yaitu: tepat pelaku, tepat lokasi, tepat kegiatan, serta tepat penyaluran dan pengembalian (Pusat Pembiayaan Pembangunan Hutan, 2016b) menjadi parameter penelitian. Penelitian ini akan menjelaskan bagaimana petani melaksanakan aturan yang dibuat pemerintah dengan adanya program PTT di Kabupaten Blora dan Wonosobo.

\section{A. Tempat Penelitian}

Penelitian dilakukan di Kabupaten Blora dan Kabupaten Wonosobo, Provinsi Jawa Tengah pada desa yang sudah mendapatkan layanan PTT. Desa-desa tersebut antara lain: Desa Waru, Desa Soko, Desa Jatirejo, Desa Plantungan, Desa Ngampel, Desa Tempuran, dan Desa Jurangjero (Kabupaten Blora) dan Desa Kalimendong, Desa Kaliputih, Desa Bojasari, dan Desa Karangsari (Kabupaten Wonosobo).

\section{B. Metode}

Penelitian menggunakan pendekatan kuantitatif dengan metode survei. Pengambilan sampel dilakukan secara purposive sampling (Palys, 2008) pada petani yang mengikuti PTT (debitur) dan petani yang tidak mengikuti PTT (non debitur) dengan jumlah responden sebanyak 222 orang, tergabung dalam Kelompok Tani Hutan Rakyat (KTHR) di tiap desa sampel. Pengumpulan data dan informasi dilakukan melalui wawancara secara berkelompok maupun perseorangan untuk menggali informasi terkait dengan tujuan penelitian, serta studi dokumen. 


\section{Analisis Statistik Deskriptif}

Analisis statistik deskriptif digunakan untuk menggambarkan bagaimana pemahaman dan pelaksanaan lapangan dengan ketentuan PTT. Ketentuan dimaksud terlihat pada bagaimana petani berkomitmen dengan prinsip 4T sesuai peraturan Kepala Pusat P2H No. P.4/P2H/APK/ SET.1/11/2016.

\section{III.HASIL DAN PEMBAHASAN}

Kebutuhan kayu secara global menjadi potensi untuk dapat meningkatkan pendapatan petani (Darusman \& Hardjanto, 2006; Awang et al., 2001). Produksi kayu dari hutan rakyat terus mengalami peningkatan dalam periode 2011-2013 (Kemenhut, 2012; Kemenhut, 2013; KLHK, 2014). Pasokan kayu hutan rakyat sekitar 70-90\% (Hardjanto, 2006) diharapkan dapat terus dipertahankan. Prinsip 4T menjadi penting dalam penyaluran dana pinjaman (Pusat Pembiayaan Pembangunan Hutan, 2016b; Sanudin \& Awang, 2019). Penelitian ini mencoba untuk menjelaskan berbagai kendala dan saran perbaikan dalam mekanisme pelaksanaan PTT.

\section{A. Sumber Informasi}

Sejauh mana informasi PTT dapat dipahami dan diketahui petani, ditentukan oleh sebaran informasi dan asal sumber informasi. Informasi yang diterima dapat mempengaruhi keinginan petani untuk berpartisipasi atau tidak. Informasi PTT meliputi tujuan program PTT, persyaratan menjadi anggota, cara pengagunan pohon, dan instansi pemberi pinjaman.

Sebaran informasi tentang PTT banyak diperoleh dari KTHR, yaitu sekitar 81,53\%. Informasi ini menjelaskan bahwa banyak petani yang tergabung dalam KTHR dan peran KTHR sangat penting dalam menyampaikan berbagai informasi kepada petani, terlepas dari karakteristik yang dimiliki petani tersebut. Peran penyuluh dan pendamping lapangan BLU (penyelia operasional/PO) juga sangat penting dalam memberikan keakuratan informasi PTT sehingga permasalahan ketidaksesuaian informasi dapat dihindari (Sanudin, Awang, Sadono, \& Purwanto, 2016) dan pendampingan intensif melalui KTHR untuk meningkatkan pengetahuan dan keterampilan pengusahaan HR (Luan \& Bauer, 2016). Sebaran informasi di kedua kabupaten disajikan pada Tabel 1.

Ketersedian informasi yang diperoleh dapat dikaitkan dengan keinginan petani non debitur untuk mengikuti PTT. Petani non debitur di Blora yang ingin mengikuti PTT sebanyak $45,65 \%$ tetapi tidak dapat berpartisipasi karena beberapa hal, yaitu: gagal verifikasi, agunan pohon masih berukuran kecil, sebagian mengundurkan diri karena realisasi kredit tidak diambil (jumlah uang tidak sesuai pengajuan), dan pembagian termin yang membuat kebutuhan tidak terpenuhi. Sisanya, sekitar 54,35\% memang tidak ingin mengikuti program PTT

Tabel 1 Sumber informasi program PTT

Table 1 PTT programme information source

\begin{tabular}{|c|c|c|c|c|c|c|}
\hline \multirow{3}{*}{ Sumber informasi (Information source) } & \multicolumn{4}{|c|}{ Kabupaten (Regency) } & \multirow{2}{*}{\multicolumn{2}{|c|}{ Jumlah (Total) }} \\
\hline & \multicolumn{2}{|c|}{ Blora } & \multicolumn{2}{|c|}{ Wonosobo } & & \\
\hline & $\begin{array}{c}\text { Orang } \\
\text { (People) }\end{array}$ & $\%$ & $\begin{array}{c}\text { Orang } \\
\text { (People) }\end{array}$ & $\%$ & $\begin{array}{c}\text { Orang } \\
(\text { People })\end{array}$ & $\%$ \\
\hline Penyuluh kehutanan (Forestry extension) & 13 & 13,13 & 16 & 13,01 & 29 & 13,06 \\
\hline KTHR (Farmer group) & 78 & 78,78 & 103 & 83,74 & 181 & 81,53 \\
\hline Pendamping (Field assistant) & 8 & 8,08 & 4 & 3,25 & 12 & 5,40 \\
\hline Jumlah (Total) & 99 & 100 & 123 & 100 & 222 & 100 \\
\hline
\end{tabular}

Sumber (Source): Data primer 2016, diolah (Primary data 2016, processed). 
karena beberapa alasan, antara lain: tidak ingin terikat kontrak, tidak ingin berhutang yang akan menjadi beban, kesadaran tidak memenuhi persyaratan (pohon jati agunan masih kecil), persyaratan terlalu rumit, sudah tercukupinya kebutuhan dari usaha sendiri, dan tidak terlalu membutuhkan pinjaman. Petani non debitur di Wonosobo yang berkeinginan mengikuti PTT hanya 7,41\% dan tidak dapat berpartisipasi karena gagal verifikasi dan kelanjutan proses pengajuan proposal yang tidak diketahui. Sisanya, sekitar 92,5\% tidak ingin mengikuti program PTT karena tidak ingin berhutang, pohon agunan belum cukup umur, tidak berminat, dan belum ada verifikasi atau tindak lanjut dari tim BLU.

\section{B. Proses Pinjaman}

Prosedur pinjaman merupakan rangkaian proses yang dilalui petani, mulai dari pengajuan hingga pengembalian kredit. Proses dimulai dari pembuatan proposal, pengajuan permohonan pinjaman, analisis administrasi, verifikasi-klarifikasi lapangan, pencairan pinjaman, dan pengembalian pinjaman. Pembuatan proposal merupakan awal persyaratan dalam pengajuan pinjaman.

Untuk kelengkapan data pada prinsip tepat pelaku, proposal pinjaman menjadi hal penting karena berisi dokumen, antara lain: surat permohonan pinjaman, data pemohon pinjaman hutan rakyat, copy data diri petani, surat keterangan
Kepala Desa perihal penguasaan lahan, tallysheet pohon, peta persil anggota petani, Rencana Definitif Kebutuhan Kelompok (RDKK), copy dokumen profil KTH, surat pernyataan pengajuan pinjaman, dan surat kesepakatan pendamping. Untuk verifikasi administrasi berupa penyiapan identitas diri (KTP asli/KK) dan bukti penguasaan lahan. Pemahaman petani terkait proses pinjaman, sebanyak 71 orang $(58,20 \%)$ menyatakan tidak sederhana dan 20 orang $(16,39 \%)$ menyatakan sederhana. Penilaian pemahaman petani debitur dari aspek proses pinjaman disajikan pada Tabel 2 .

Proses pinjaman sederhana, ketika petani merasa dimudahkan dalam hal pengurusan persyaratan pengajuan. Petani menyerahkan urusan pemberkasan kepada pengurus KTHR karena pengajuan bersifat kolektif dan dikerjakan oleh beberapa orang saja atau pengurus KTHR. Proses pinjaman tidak sederhana karena petani mengeluhkan persyaratan rumit/sulit, administrasi berbelit, dan waktu pencairan pinjaman yang cukup lama. Kegiatan sering kumpulan/ rapat dipandang sebagian petani sangat menggangu waktu dan aktivitas bekerja; selain itu, terlalu rumitnya administrasi dalam tulis-menulis atau terlalu banyak memberikan tanda tangan pada kehadiran sosialisasi dan kesepakatan kontrak, serta waktu menunggu verifikasi terlalu lama.

Persyaratan rumit dan berbelit bagi petani Blora secara spesifik dipahami

Tabel 2 Pernyataan petani debitur terhadap proses pinjaman

Table 2 Statement of debtor farmer to the loan process

\begin{tabular}{|c|c|c|c|c|c|c|}
\hline \multirow{3}{*}{ Jawaban petani (Farmer's answer) } & \multicolumn{4}{|c|}{ Kabupaten (Regency) } & \multirow{2}{*}{\multicolumn{2}{|c|}{ Jumlah (Total) }} \\
\hline & \multicolumn{2}{|c|}{ Blora } & \multicolumn{2}{|c|}{ Wonosobo } & & \\
\hline & $\begin{array}{c}\text { Orang } \\
\text { (People) }\end{array}$ & $\%$ & $\begin{array}{c}\text { Orang } \\
\text { (People) }\end{array}$ & $\%$ & $\begin{array}{c}\text { Orang } \\
\text { (People) }\end{array}$ & $\%$ \\
\hline Proses sederhana (Simple process) & 13 & 24,53 & 7 & 10,14 & 20 & 16,39 \\
\hline $\begin{array}{l}\text { Proses kurang sederhana (Less simple } \\
\text { process) }\end{array}$ & 10 & 18,87 & 21 & 30,44 & 31 & 25,41 \\
\hline $\begin{array}{l}\text { Proses tidak sederhana (Complicated } \\
\text { process) }\end{array}$ & 30 & 56,60 & 41 & 59,42 & 71 & 58,20 \\
\hline Jumlah (Total) & 53 & 100 & 69 & 100 & 122 & 100 \\
\hline
\end{tabular}

Sumber (Source): Data primer 2016, diolah (Primary data 2016, processed). 
bahwa semula legalitas pemilikan lahan dapat menggunakan Surat Pemberitahuan Pajak Terutang (SPPT) sebagai persyaratan, namun berubah dan SPPT tidak berlaku, melainkan harus menggunakan letter $\mathrm{C} / \mathrm{D}$ atau akta jual/beli atau sertifikat tanah. Rata-rata tanah petani tidak memiliki sertifikat tetapi letter $\mathrm{C} / \mathrm{D}$. Proses penerbitan petikan letter $\mathrm{C} / \mathrm{D}$ dipersepsikan rumit bagi sebagian orang desa karena harus melihat sejarah pemilikan lahan dalam buku induk "rahasia" desa. Selanjutnya, menelusuri melalui klarifikasi dan keterangan surat warisan/hibah serta para saksi hingga cukup jelas sampai kepada nama hak pemiliknya. Perubahan riwayat pemilik asli yang tertera di letter C/D menjadi atas nama anak, cucu, buyut, atau bahkan sudah pernah mengalami proses lelang/jual beli lahan, dianggap rumit dalam penerbitan letter C/D. Lag time merupakan waktu yang dibutuhkan oleh petani untuk mendapatkan dana PTT, mulai dari pengusulan hingga realisasi pencairan. Tata waktu yang tidak jelas dan tidak pasti membuat petani merasa proses PTT menjadi lama. Gambar 1 menjelaskan lag time, mulai dari pengusulan PTT hingga realisasi pencairan sekitar \pm 5-6 bulan.

Petani di Blora dan Wonosobo merespon proses pinjaman rumit karena waktu yang diperlukan untuk pencairan sekitar satu tahun. Tata waktu enam bulan yang dibutuhkan sampai pencairan PTT, walaupun sesuai prosedural, masih dianggap terlalu lama, apalagi menunggu sampai 1 tahun sehingga tidak dapat memenuhi kebutuhan mendesak. Lamanya proses PTT menimbulkan keputusasaan dan kekecewaan petani pada program PTT. Titik kritis lag time adalah pada saat tidak adanya lagi kesabaran petani untuk menunggu sehingga dapat melakukan penebangan atau batal berpartisipasi dalam program PTT akibat masuknya pengijon atau tengkulak yang dapat mempengaruhi petani. Pada saat perilaku menebang terjadi maka pinjaman menjadi tidak efektif, walaupun disadari bahwa semakin lama pohon berdiri sesungguhnya akan meningkatkan nilai ekonomi pohon tersebut.

Petani mengeluhkan lamanya waktu karena ada proses persiapan dan administrasi yang wajib dilakukan sebelum pengajuan proposal. Proses tersebut berupa pendataan pohon melalui tallysheet (inventarisasi) yang dianggap merepotkan, memberi penanda pohon, dan persiapan berkas persyaratan. Selain itu, ada proses menunggu persiapan dari KTHR lain agar kolektif mengajukan, verifikasi lapangan (field analysis) yang lambat diproses BLU, dan tidak adanya kepastian waktu pencairan pinjaman menambah daftar keluhan petani karena waktu yang dibutuhkan terkesan lama.

Nugroho et al. (2017) menjelaskan waktu pengajuan kredit sampai pada akad kredit membutuhkan waktu lama karena kesepakatan Gapoktan Jati Mustika di Blora untuk bersama-sama mengajukan pinjaman kepada BLU. Konsekuensinya adalah waktu bertambah lama dan menimbulkan

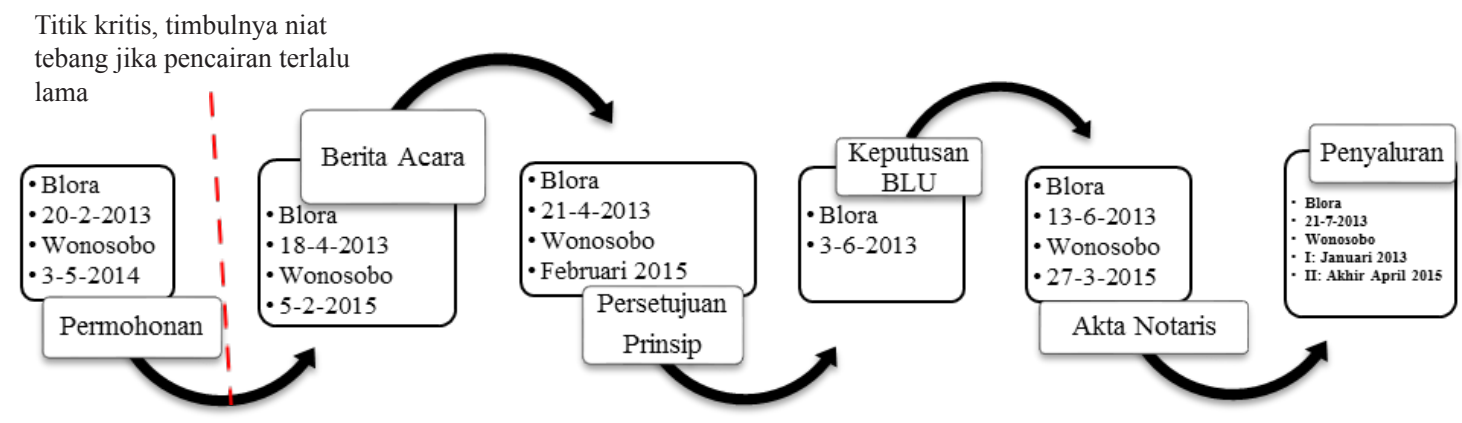

Gambar 1 Lag time penyaluran PTT

Picture 1 Lag time of PTT disbursement. 
kekecewaan sehingga dapat mempengaruhi keinginan petani untuk melanjutkan program PTT. Sebagaimana disampaikan pengurus KTHR di Desa Kaliputih, Wonosobo bahwa ketika KTHR Sejahtera sudah selesai pemberkasan dan siap mengajukan proposal, masih harus menunggu persiapan proposal dari KTHR lain agar diusulkan secara kolektif.

\section{Ketaatan Kontrak Perjanjian}

Kontrak pinjaman merupakan aturan terkait ketaatan petani untuk menjaga pohon agunan dengan tidak menebang pohon selama jangka waktu pinjaman dan memelihara penanda pohon. Praktik di lapangan, masih ada petani yang melakukan penebangan dan tidak memelihara penanda pohon atau "keplek" sebagai bukti pohon agunan. Penanda pohon berisi data keliling pohon dan nomor pohon. Pada umumnya petani mengeluhkan "keplek" yang tidak dapat bertahan lama dan mempengaruhi penilaian saat verifikasi lapangan dan monitoring evaluasi BLU untuk lolostidaknya menjadi debitur, atau terjadi pembatalan pencairan tahap berikutnya bagi yang telah menjadi debitur. Pengamatan lapangan terkait ketaatan kontrak, disajikan pada Tabel 3.

Alasan petani Blora melakukan tebangan pohon agunan $(22,65 \%)$ disebabkan antara lain: memenuhi kebutuhan, renovasi rumah, kondisi pohon rusak/mati akibat roboh atau tersambar petir atau serangan jamur. Keputusan petani Wonosobo untuk menebang pohon sebelum jatuh tempo karena pohon sengon yang dominan menjadi agunan terkena hama dan penyakit. Sebanyak 99\% debitur melakukan penebangan pohon yang diagunkan. Risiko kerugian mempertahankan tegakan yang terserang hama penggerek batang, jamur upas, atau karat puru sangatlah besar. Sewaktu-waktu pohon dapat mati dan roboh sehingga merusak tanaman bawah atau tegakan lainnya dan menulari tegakan sehat lainnya. Karat tumor atau karat puru merupakan penyakit sengon yang dapat mematikan, bahkan pada tingkat tegakan sekalipun (Irawanti, Aneka, \& Ekawati, 2012). Kerugian ini dirasakan sangat signifikan bagi petani di Wonosobo terkait eksistensi mempertahankan sumber penghasilan jangka pendek dari hutan rakyat (tanaman salak) dan pengaruh harga kayu pada saat penjualan karena cacat.

Ketaatan kontrak dapat mencerminkan itikad baik atau positif petani dalam melaksanakan komitmen. Adanya penebangan selama masa kontrak menunjukkan petani tidak memiliki itikad baik. Itikad baik diharapkan dapat menjadi pertimbangan dalam perguliran dana pinjaman selanjutnya kepada petani lain di lokasi berbeda. Implikasi dari penebangan sebagaimana kasus petani Wonosobo tentu akan menjadi pertanyaan terkait pengembalian pinjaman. Oleh karena itu, BLU perlu mempertimbangkan penebangan pohon karena serangan hama dan penyakit (force majeure) dan melakukan penelitian lebih lanjut terhadap jenis-jenis tanaman

Tabel 3 Ketaatan petani debitur terhadap kontrak pinjaman Table 3 Debtor farmer pursuance to the loan contract

\begin{tabular}{|c|c|c|c|c|}
\hline \multirow{2}{*}{$\begin{array}{c}\text { Ketaatan kontrak } \\
\text { (Contract compliance) }\end{array}$} & \multicolumn{4}{|c|}{$\begin{array}{c}\text { Komitmen terhadap kontrak perjanjian PTT } \\
(\text { Commitment to the PTT contract })(\%)\end{array}$} \\
\hline & \multicolumn{2}{|c|}{$\begin{array}{l}\text { Kabupaten Blora } \\
\text { (Blora Regency) }\end{array}$} & \multicolumn{2}{|c|}{$\begin{array}{l}\text { Kabupaten Wonosobo } \\
\text { (Wonosobo Regency) }\end{array}$} \\
\hline $\begin{array}{l}\text { Tidak menebang pohon agunan } \\
\text { dan menjaga penanda pohon }\end{array}$ & $\begin{array}{l}\text { Menebang } \\
\text { (Harvesting) }\end{array}$ & $\begin{array}{l}\text { Tidak menebang } \\
\text { (No cutting) }\end{array}$ & $\begin{array}{l}\text { Menebang } \\
\text { (Harvesting) }\end{array}$ & $\begin{array}{l}\text { Tidak menebang } \\
\text { (No cutting) }\end{array}$ \\
\hline $\begin{array}{l}\text { agunan (No cutting and maintain } \\
\text { collateral tree labels) }\end{array}$ & 22,65 & 72,58 & 99 & 1 \\
\hline
\end{tabular}

Sumber (Source): Data primer 2016, diolah (Primary data 2016, processed). 
hutan yang akan menjadi agunan dalam PTT. Kecenderungan petani bersikap negatif terhadap pelaksanaan PTT dapat dipengaruhi oleh motivasi menebang dan pendapatan petani untuk memenuhi kebutuhannya (Wibowo \& Haryadi, 2006).

\section{Manfaat Perjanjian}

Manfaat pinjaman ada yang dirasakan dan dinilai positif maupun negatif. Pemahaman petani terkait manfaat PTT terbagi menjadi dua, yaitu petani yang merasakan manfaat PTT dan petani yang tidak merasakan manfaat pinjaman. Petani yang merasakan manfaat pinjaman di Blora sebesar 98,41\% dan di Wonosobo sebesar 89,16\%. Persepsi petani terhadap manfaat pinjaman disajikan pada Tabel 4.

Manfaat pinjaman yang dirasakan petani, antara lain:

1. Pohon masih terjaga.

2. Bunga pinjaman lebih ringan dan lunak.

3. Memenuhi kebutuhan petani.

4. Menambah modal usaha.

5. Tanaman lain menjadi lebih produktif.

Pemahaman petani dalam menjaga pohon pada umur muda hingga daur dapat meningkatkan pertumbuhan sehingga kualitas pohon menjadi bagus, dapat memberikan nilai ekonomi yang optimal karena kayu bertumbuh lebih besar, lingkungan lebih lama terjaga, dan dana PTT mampu memenuhi kebutuhan petani tanpa harus menebang pohon umur muda.

Upaya mempertahankan pohon muda dengan tidak menebang terlalu sering, dapat mencegah kerusakan tanaman bawah (kopi dan salak) dan dapat digunakan sebagai persyaratan agunan dalam mengajukan PTT. Bunga pinjaman yang diberikan BLU sesuai BI rate pada saat akad kredit dan bersifat flat selama jangka waktu pinjaman. Bunga pinjaman yang ringan dan lunak dirasakan memberi keuntungan kepada petani dan menimbulkan minat petani untuk mengagunkan pohonnya, hal ini bersifat positif terkait keberlanjutan tegakan atau pohon agunan. Adanya uang tunai PTT dapat membantu pemenuhan kebutuhan petani, baik yang bersifat mendesak atau tidak. Kebutuhan petani dalam jumlah besar seperti biaya pendidikan, membayar hutang, mencukupi kebutuhan pokok harian, merenovasi rumah, dan membeli motor dapat teratasi dengan dana talangan dari pinjaman tanpa harus mengorbankan pohon, terlebih pohon yang masih berumur muda atau harus meminjam uang dari sumber lain dengan jaminan surat berharga. PTT dapat menambah modal usaha seperti usaha ternak, usaha tani, usaha perikanan, usaha jasa, usaha dagang, dan usaha lainnya. Peruntukan sebagai modal usaha dimaksudkan petani untuk meningkatkan pendapatan, perluasan bisnis/usaha keluarga, menambah aset, menjaga pemenuhan kebutuhan, bahkan sebagian petani sudah mempersiapkan uang hasil usaha untuk pembayaran tagihan PTT tanpa harus menebang pohon.

Persepsi petani yang tidak merasakan manfaat PTT, antara lain:

1. Dana yang diterima tidak sesuai pengajuan.

2. Dana tidak cukup untuk modal usaha.

3. Taksiran harga kayu dari BLU yang rendah.

Tabel 4 Persepsi petani debitur terhadap manfaat pinjaman Table 4 Perception of debtor farmer to the loan benefit

\begin{tabular}{lcc}
\hline Uraian (Description) & $\begin{array}{c}\text { Kabupaten Blora } \\
\text { (Blora Regency) }\end{array}$ & $\begin{array}{c}\text { Kabupaten Wonosobo } \\
\text { (Wonosobo Regency) } \\
(\%)\end{array}$ \\
\hline Merasakan manfaat pinjaman (Useful loan) & 98,41 & 89,16 \\
Tidak merasakan manfaat pinjaman (Useless loan) & 1,59 & 10,84 \\
\hline Jumlah (Total) & 100 & 100 \\
\hline
\end{tabular}

Sumber (Source): Data primer 2016, diolah (Primary data 2016, processed). 
4. Jangka waktu pencairan yang lama sehingga tidak sesuai perencanaan.

5. Baru satu tahunjangkawaktu peminjaman sudah diwajibkan mengembalikan PTT.

Berbagai keluhan menjadi alasan petani tidak menaati komitmen dan memicu terjadinya penebangan.

\section{E. Kepuasan Mekanisme PTT}

Kepuasan mekanisme PTT dapat dilihat dari perbandingan dengan tengkulak, khususnya dalam mendapatkan uang atau pemasaran kayu. Lebih dari 55\% petani mengatakan puas dengan mekanisme BLU karena petani diuntungkan, dalam hal:

1. Estimasi harga kayu dari BLU lebih tinggi daripada tengkulak, meskipun di pasaran harga dapat lebih tinggi. Berdasarkan persepsi petani yang tidak puas dengan taksiran harga BLU, fakta lapangan menunjukkan petani merasa puas dengan estimasi harga BLU dibandingkan tengkulak.

2. Tersedianya dana talangan, baik untuk modal usaha maupun memenuhi kebutuhan mendesak.

Persepsi petani terhadap perbandingan BLU dengan tengkulak disajikan pada Tabel 5.

Alasan ketidakpuasan petani, antara lain:

1. Penerimaan uang yang belum genap tahap pencairan di tahun berikutnya, tetapi petani sudah mendapat surat tagihan. Walaupun hal ini sesuai dengan aturan pinjaman, namun memberatkan bagi petani sehingga perlu dipertimbangkan dalam proses pinjaman selanjutnya. Selain itu, hal ini dikarenakan sebelum proses pencairan tahap berikutnya, diadakan evaluasi lapangan oleh tim BLU dan hasil menunjukkan pohon agunan banyak yang ditebang sebelum jatuh tempo sehingga harus diberikan surat tagihan tanpa ada pencairan tahap berikutnya.

2. Proses dan prosedur BLU yang rumit dan membutuhkan waktu lama sehingga petani merasa kecewa, terlebih untuk memenuhi kebutuhan mendesak.

3. Melalui tengkulak lebih cepat mendapatkan uang tunai karena proses penjualan lebih mudah dan sederhana.

4. Pelayanan BLU yang dianggap kurang memuaskan karena PO yang sedianya dapat intensif membantu petani di lapangan, sering berganti personil dan sulit dihubungi untuk berkoordinasi, khususnya di wilayah Wonosobo.

Realisasi atau pencairan pinjaman dapat juga menjadi penyebab ketidakpuasan petani terhadap mekanisme BLU. Persepsi petani terkait realisasi pinjaman berdasarkan pengajuan pinjaman disajikan pada Tabel 6 .

Respon petani terkait realisasi uang yang diterima tidak sesuai pengajuan, karena berbagai faktor, antara lain: pencairan yang dibagi termin, nominal pinjaman dibatasi (credit limit), dan fakta nilai pohon agunan di pasaran lebih besar dari taksiran harga BLU. Pemahaman terkait realisasi pinjaman yang sesuai, antara lain: umumnya petani mengagunkan pohon dalam jumlah sedikit atau kebutuhannya sedikit/sudah tercukupi, pilihan meminjam semata-mata untuk memanfaatkan pinjaman dan tetap mempertahankan pohon hingga siap tebang sesuai daur.

Tabel 5 Perbandingan kepuasan mekanisme PTT dengan tengkulak

Table 5 Ratio of the PTT mechanism satification to the middleman

\begin{tabular}{lcc}
\hline Mekanisme PTT (PTT mechanism) & $\begin{array}{c}\text { Kabupaten Blora } \\
\text { (Blora Regency) }(\%)\end{array}$ & $\begin{array}{c}\text { Kabupaten Wonosobo } \\
\text { (Wonosobo Regency) }(\%)\end{array}$ \\
\hline Puas (Satisfy) & 56,52 & 55,41 \\
Tidak puas (Unsatisfied) & 43,48 & 44,59 \\
\hline Jumlah (Total) & 100 & 100 \\
\hline
\end{tabular}

Sumber (Source): Data primer 2016, diolah (Primary data 2016, processed). 
Tabel 6 Realisasi pinjaman berdasarkan pengajuan

Table 6 Loan realization based on the proposal

\begin{tabular}{lcc}
\hline Realisasi pinjaman (Loan realization) & $\begin{array}{c}\text { Kabupaten Blora } \\
\text { (Blora Regency) (\%) }\end{array}$ & $\begin{array}{c}\text { Kabupaten Wonosobo } \\
\text { (Wonosobo Regency) }(\%)\end{array}$ \\
\hline $\begin{array}{l}\text { Nilai pinjaman sesuai permohonan (Suitable } \\
\text { loan) }\end{array}$ & 60,38 & 50,72 \\
$\begin{array}{l}\text { Nilai pinjaman tidak sesuai permohonan } \\
\text { (Unsuitable loan) }\end{array}$ & 39,62 & 49,28 \\
\hline Jumlah (Total) & 100 & 100 \\
\hline
\end{tabular}

Sumber (Source): Data primer 2016, diolah (Primary data 2016, processed).

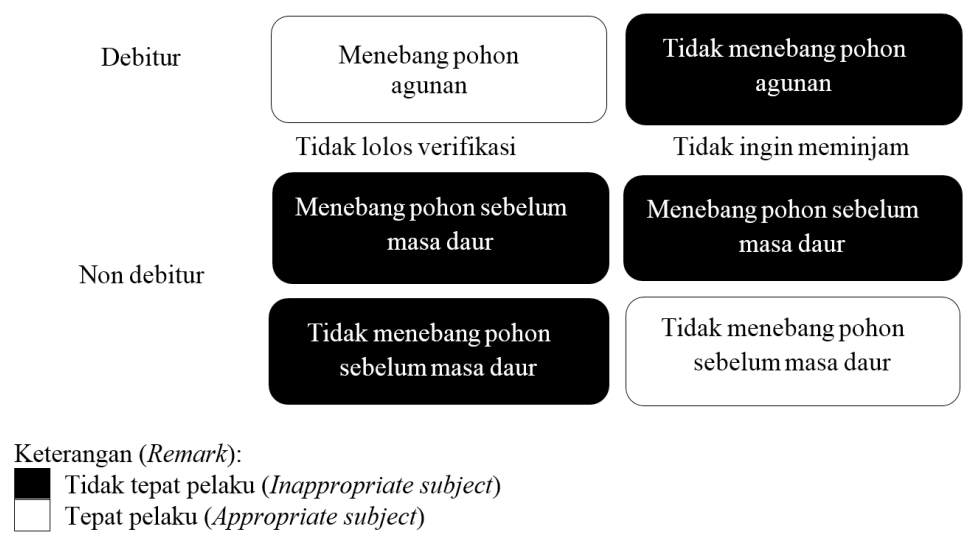

Gambar 2 Tepat pelaku berdasarkan perilaku menebang

Picture 2 Approprite subject based on harvesting behaviour.

\section{F. Prinsip Pinjaman}

Implementasi PTT dapat dilihat berdasarkan ketentuan kriteria prinsip 4T, yaitu: tepat pelaku, tepat lokasi, tepat kegiatan, serta tepat penyaluran dan pengembalian.

\section{Prinsip Tepat Pelaku}

Prinsip tepat pelaku adalah kesesuaian identitas pemohon dengan KTP/KK pemohon, kesesuaian identitas pemohon dengan bukti penguasaan lahan, dan keabsahan dokumen persyaratan administratif. Petani Blora dan Wonosobo yang menjadi debitur PTT di lokasi penelitian sudah mendapat persetujuan secara administratif dari BLU. Dari 344 pemohon PTT di Blora, hanya 144 orang yang disetujui menjadi debitur, sedangkan dari 134 orang pemohon di Wonosobo, hanya 88 orang yang disetujui menjadi debitur.
Hal ini dapat dipahami bahwa pihak BLU mencoba menghindari kesalahan sasaran dengan tepat pelaku kredit saat verifikasi dan klarifikasi administrasi.

Karakter pemahaman petani terkait PTT berdasarkan perilaku menebang di Kabupaten Blora dan Wonosobo, yaitu masih ada petani debitur yang menebang pohon agunan dan petani non debitur yang melakukan penebangan atau tidak menebang. Karakter petani non debitur dapat dibedakan menjadi non debitur yang tidak ingin berhutang, tidak ingin mengikuti PTT dan petani yang tidak lolos verifikasi PTT. Keragaman karakter petani hutan rakyat disajikan pada Gambar 2.

Perilaku petani debitur yang menebang pohon agunan merupakan pelanggaran terhadap komitmen bersama atau keparalegalan. Karakter petani seperti ini yang sebenarnya menjadi sasaran 
tepat pelaku untuk menerima PTT dalam memenuhi kebutuhan mendesaknya. Petani non debitur yang tidak ingin berhutang dan tidak menebang pohon sebelum masa daur dapat menjadi contoh bagi perilaku "taat azas" yang dapat mencerminkan tepat pelaku. Prinsip tepat pelaku berdasarkan verifikasi dan klarifikasi identitas dan keabsahan penguasaan lahan tidak cukup menentukan sebagai dasar "tepat pelaku".

Pendidikan, umur, informasi sekitar dan pemahaman terhadap program PTT perlu menjadi bahan pertimbangan tambahan untuk menentukan prinsip tepat pelaku dalam pendistribusian PTT. Tujuan program PTT adalah untuk menghindari penebangan pohon pada saat petani membutuhkan dana segar atau menghindari peluang pengijon di mana kayu telah terjual namun masih bertumbuh di lahan milik petani (Pusat Pembiayaan Pembangunan Hutan, 2016a). Prinsip tepat pelaku perlu lebih dipahami terkait tujuan PTT, yaitu menghindari penebangan pohon yang belum masa daur. Penebangan pohon tidak sesuai daur akan merugikan petani dalam hal manfaat ekonomi jangka panjang saat pohon tersebut dapat memiliki nilai lebih tinggi.

Selain itu, persyaratan legalitas kepemilikan lahan menjadi tolak ukur prinsip tepat pelaku. Banyak petani yang ingin menjadi debitur tetapi tidak lolos verifikasi administrasi. Kondisi tepat pelaku hanya dilihat berdasarkan persyaratan administrasi. Ada distorsi pemahaman dari BLU bahwa berniat membantu petani untuk mendapatkan PTT tetapi petani merasa kesulitan mengakses PTT karena kendala administrasi dan rumitnya persyaratan sehingga perlu dilakukan perbaikan persyaratan administrasi. Bagi petani, persyaratan yang mudah dipenuhi adalah dengan menunjukkan legalitas pemilikan lahan berupa SPPT sebagaimana persyaratan awal sosialisasi. Hasil penelitian menunjukkan bahwa penentuan tepat pelaku lebih difokuskan pada penggalian komitmen petani melalui diskusi dan wawancara mendalam oleh BLU.

\section{Prinsip Tepat Lokasi}

Prinsip tepat lokasi berkaitan dengan aspek biofisik lahan, meliputi: keberadaan lahan yang jelas kepemilikannya, persil lahan sesuai dengan bukti penguasaan lahan atau kepemilikan, aksesibilitas, dan pohon sudah laku jual tetapi belum masa daur. Hasil pengamatan dengan kriteria prinsip tepat lokasi disajikan pada Tabel 7 .

Tabel 7 Pengamatan lapangan dengan kriteria prinsip tepat lokasi

Table 7 Field observation by principal criteria of appropriate location

\begin{tabular}{|c|c|c|}
\hline \multirow[b]{2}{*}{ Kriteria (Criteria) } & \multicolumn{2}{|c|}{ Pengamatan (Observation) } \\
\hline & $\begin{array}{l}\text { Kabupaten Blora } \\
\text { (Blora Regency) }\end{array}$ & $\begin{array}{l}\text { Kabupaten Wonosobo } \\
\text { (Wonosobo Regency) }\end{array}$ \\
\hline $\begin{array}{l}\text { a. Keberadaan lahan yang jelas } \\
\text { (Clear land status })\end{array}$ & $\begin{array}{l}\text { Lahan hutan rakyat petani memiliki } \\
\text { bukti kepemilikan (tidak fiktif) }\end{array}$ & $\begin{array}{l}\text { Lahan hutan rakyat petani } \\
\text { memiliki bukti kepemilikan } \\
\text { (tidak fiktif) }\end{array}$ \\
\hline $\begin{array}{l}\text { b. Persil lahan petani sesuai } \\
\text { dengan bukti penguasaan lahan } \\
\text { (Ownership land) }\end{array}$ & $\begin{array}{l}\text { Bukti kepemilikan jelas, ada bukti } \\
\text { letter } \mathrm{C} / \mathrm{D} \text { atau sertifikat }\end{array}$ & $\begin{array}{l}\text { Bukti kepemilikan jelas, ada } \\
\text { bukti letter C/D atau sertifikat }\end{array}$ \\
\hline c. Aksesibilitas (Accessibility) & $\begin{array}{l}\text { Dapat dicapai/didatangi meskipun } \\
\text { tergolong akses mudah, sedang, dan } \\
\text { sulit }\end{array}$ & $\begin{array}{l}\text { Dapat dicapai/didatangi } \\
\text { meskipun tergolong akses } \\
\text { mudah, sedang, dan sulit }\end{array}$ \\
\hline $\begin{array}{l}\text { d. Sudah laku jual, belum masak } \\
\text { tebang (Ready sold and young } \\
\text { trees) }\end{array}$ & $\begin{array}{l}\text { Pohon agunan minimal berukuran } \\
20 \mathrm{~cm}(\varnothing \pm 7 \mathrm{~cm})\end{array}$ & $\begin{array}{l}\text { Pohon agunan minimal } \\
\text { berukuran } 30 \mathrm{~cm}(\varnothing \pm 10 \mathrm{~cm})\end{array}$ \\
\hline
\end{tabular}

Sumber (Source): Data primer dan sekunder 2016, diolah (Primary and secondary data 2016, processed). 
Kepemilikan lahan yang jelas dan bukti kepemilikan dapat menghindari sengketa (Napitu, Hidayat, Basuni, \& Sjaf, 2017) sehingga lahan tidak fiktif dan pohon yang menjadi agunan dapat memenuhi persyaratan PTT. Aksesibilitas lahan yang dapat didatangi akan berpengaruh pada pemasaran kayu. Pohon agunan yang dipersyaratkan adalah jenis komersial dengan ketentuan minimal sudah laku jual tetapi belum masak tebang. Hal ini akan berdampak pada nilai agunan pohon dan potensi mengembalikan pinjaman.

Berdasarkan kriteria yang digunakan oleh BLU, sebagai dasar penyaluran dana PTT kepada debitur telah sesuai dengan prinsip tepat lokasi karena telah memenuhi persyaratan kriteria. Pada kenyataanya aktivitas penebangan tetap terjadi di lapangan sebagaimana alasan petani melakukan penebangan untuk memenuhi kebutuhan. Tepat lokasi, sesuai kriteria ternyata tidak menjamin bahwa petani tidak melakukan penebangan. Walaupun petani di Blora dan Wonosobo masuk kriteria tepat lokasi namun kebutuhan akan pinjaman untuk memenuhi kebutuhan petani yang sangat mendesak harus menjadi pertimbangan utama. Selain mempertimbangkan kriteria tepat pelaku dan tepat lokasi, BLU perlu mendalami komitmen petani dan penentuan jenis tanaman yang tidak mudah terserang hama dan penyakit, untuk menjadi agunan PTT.

\section{Prinsip Tepat Kegiatan}

Prinsip tepat kegiatan dapat dilihat dari bagaimana pelaksanaan di lapangan, prinsip tepat kegiatan meliputi:

a. Penyebaran lokasi relatif kompak dan mudah dijangkau atau dikelola KTH.

b. Memiliki tenaga pendampingan.

c. Adanya dukungan pemerintah daerah.

Hasil pengamatan tentang prinsip tepat kegiatan disajikan pada Tabel 8.

Keterjaminan tegakan dapat dikatakan sebagai "taat asas" petani debitur terhadap pelaksanaan program PTT. Keterjaminan

Tabel 8 Pengamatan lapangan dengan kriteria prinsip tepat kegiatan

Table 8 Field observation by principal criteria of appropriate location

\begin{tabular}{|c|c|c|}
\hline \multirow[b]{2}{*}{ Kriteria (Criteria) } & \multicolumn{2}{|c|}{ Pengamatan (Observation) } \\
\hline & $\begin{array}{l}\text { Kabupaten Blora } \\
\text { (Blora Regency) }\end{array}$ & $\begin{array}{l}\text { Kabupaten Wonosobo } \\
\text { (Wonosobo Regency) }\end{array}$ \\
\hline $\begin{array}{l}\text { 1. Itikad dan karakter positif } \\
\text { (ketaatan tidak menebang } \\
\text { dan menjaga pohon agunan) } \\
\text { (Farmer commitment) }\end{array}$ & $\begin{array}{l}\text { Sebagian petani kurang komitmen } \\
\text { terhadap kontrak perjanjian PTT. } \\
\text { Petani melakukan tebangan: } 12 \\
\text { orang }(22,65 \%) \text {, menjaga penanda } \\
\text { pohon: } 39 \text { orang }(73,58 \%) \text {. }\end{array}$ & $\begin{array}{l}\text { Hampir seluruh petani kurang } \\
\text { komitmen terhadap kontrak } \\
\text { perjanjian PTT. Petani melakukan } \\
\text { tebangan: } 68 \text { orang }(99 \%) .\end{array}$ \\
\hline $\begin{array}{l}\text { 2. Pemanfaatan PTT } \\
\text { (menghadapi masalah } \\
\text { tebang butuh/pengijon) (PTT } \\
\text { utilization) }\end{array}$ & $\begin{array}{l}\text { Penggunaan kebutuhan mendesak } \\
(56,75 \%) \text { dan kebutuhan tidak } \\
\text { mendesak }(35,14 \%) \text {. }\end{array}$ & $\begin{array}{l}\text { Penggunaan kebutuhan mendesak } \\
(31,32 \%) \text { dan kebutuhan tidak } \\
\text { mendesak }(62,64 \%) \text {. }\end{array}$ \\
\hline $\begin{array}{l}\text { 3. Penyebaran lokasi lahan } \\
\text { relatif kompak dan mudah } \\
\text { dikelola KTH (Compact } \\
\text { land distribution and easily } \\
\text { managed) }\end{array}$ & $\begin{array}{l}\text { Lokasi persil hutan rakyat tersebar } \\
\text { di dalam wilayah masing-masing } \\
\text { desa yang menjadi debitur. }\end{array}$ & $\begin{array}{l}\text { Lokasi persil hutan rakyat tersebar } \\
\text { di dalam wilayah masing-masing } \\
\text { desa yang menjadi debitur. }\end{array}$ \\
\hline 4. Pendampingan (Assistance) & $\begin{array}{l}\text { Peran KTHR dan penyuluh } \\
\text { kehutanan sangat aktif. Demikian } \\
\text { juga dengan PO BLU. }\end{array}$ & $\begin{array}{l}\text { Peran KTHR dan penyuluh } \\
\text { sangat aktif. Setelah pencairan } \\
\text { PTT, ada pergantian PO BLU dan } \\
\text { dianggap kurang komunikatif dan } \\
\text { koordinatif. }\end{array}$ \\
\hline
\end{tabular}


Tabel 8 Lanjutan

Table 8 Continued

\begin{tabular}{lll}
\hline \multirow{2}{*}{ Kriteria (Criteria) } & \multicolumn{2}{c}{ Pengamatan (Observation) } \\
\cline { 2 - 3 } & \multicolumn{1}{c}{$\begin{array}{c}\text { Kabupaten Blora } \\
\text { (Blora Regency) }\end{array}$} & \multicolumn{1}{c}{$\begin{array}{c}\text { Kabupaten Wonosobo } \\
\text { (Wonosobo Regency) }\end{array}$} \\
\hline $\begin{array}{l}\text { 5. Dukungan pemerintah } \\
\text { daerah (Support of local } \\
\text { government) }\end{array}$ & $\begin{array}{l}\text { Kepala Desa: surat pengantar } \\
\text { perihal penguasaan lahan. Kegiatan }\end{array}$ & $\begin{array}{l}\text { Kepala Desa: surat pengantar } \\
\text { perihal penguasaan lahan. }\end{array}$ \\
& $\begin{array}{l}\text { Dishut: pendampingan dari } \\
\text { penyuluh (sosialisasi, verifikasi, }\end{array}$ & $\begin{array}{l}\text { Kegiatan Dishut: pendampingan } \\
\text { dari penyuluh (sosialisasi, }\end{array}$ \\
& dan monev). & verifikasi, dan monev). \\
\hline
\end{tabular}

Sumber (Source): Data primer dan sekunder 2016, diolah (Primary and secondary data 2016, processed).

tegakan dilihat dari keinginan petani untuk tidak menebang dan memelihara penanda pohon agunan. Hasil penelitian menjelaskan bahwa masih ada petani yang menebang pohon agunan selama masa kontrak, baik di Kabupaten Blora maupun Wonosobo. Hampir semua petani di Wonosobo menebang pohon agunannya (99\%) sebagaimana terlihat pada Tabel 8 , sedangkan petani Blora yang melakukan penebangan sekitar $22,65 \%$. Pohon yang menjadi agunan petani Blora adalah jati, sedangkan pohon di Wonosobo adalah dominan sengon. Penebangan terjadi karena serangan hama dan penyakit pada tanaman sengon menjadi permasalahan serius dalam pelaksanaan PTT. Kemampuan dan keterbatasan petani dalam mencegah dan mengatasi hama dan penyakit menjadi pilihan petani apakah dapat mempertahankan pohon agunan atau menebang pohon yang mengakibatkan keparalegalan. Dibandingkan jati, pohon sengon menjadi jenis yang berisiko tinggi jika dijadikan pohon agunan karena rentan terhadap serangan hama dan penyakit. Serangan hama dan penyakit dapat menjadi suatu kondisi force majeure. BLU perlu mempertimbangkan pohon agunan jenis sengon melalui kebijakan-kebijakan khusus untuk menyelamatkan pohon agunan atau melalui asuransi hama dan penyakit.

Penanda pohon dapat dibuat dengan tanda cat pada keliling pohon ataupun menggunakan bahan terpal "keplek" yang ditulisi menggunakan spidol permanen dan dipaku (stepless) pada batang pohon. Dalam praktiknya, petani masih memiliki kendala dalam menjaga "keplek" pohon agunan jati. Spidol permanen tidak mampu bertahan dalam kondisi iklim di Blora sehingga tulisan menjadi pudar, terkadang hilang. Alasan lainnya yaitu kebiasaan petani dalam membersihkan lahan di bawah tegakan masih menggunakan metode bakar sehingga "keplek" dapat terbakar atau kehilangan informasi. Berbeda dengan Blora, hampir semua petani Wonosobo tidak dapat mempertahankan "keplek" karena hilang atau terjepit seiring pertumbuhan sengon yang "fast growing" sehingga pohon dianggap tidak ada dan tidak sesuai dengan jumlah toleransi ketika ada monitoring dan evaluasi dari tim BLU.

Alasan pinjaman ada yang bersifat urgensi berdasarkan waktu, yaitu untuk memenuhi kebutuhan mendesak dan tidak mendesak. Alasan yang termasuk dalam kebutuhan mendesak antara lain: biaya pendidikan, kebutuhan pokok harian, biaya kesehatan, membayar hutang, mencalonkan diri menjadi Kades, dan membeli aset berupa tanah (Nugroho, 2010; Nugroho et al., 2017). Alasan yang termasuk kebutuhan tidak mendesak, yaitu: modal usaha dan kebutuhan lainya (hiburan). Adjognon, Liverpool-Tasie, \& Reardon (2017) menjelaskan penggunaan kredit pada jaman modern ini untuk konsumsi finansial dan 
modal usaha non pertanian. Penggunaan dana PTT untuk konsumsi finansial biasanya untuk memenuhi kebutuhan mendesak, sedangkan modal usaha dimaksudkan petani untuk memperoleh pendapatan jangka pendek selain sebagai input untuk usaha pertaniannya.

\section{Tepat Penyaluran dan Pengembalian}

Prinsip tepat penyaluran dan pengembalian merupakan bentuk akhir komitmen bersama setelah proses verifikasi dan kesepakatan perjanjian kedua belah pihak dan masa berakhirnya kredit. Prinsip tepat penyaluran dan pengembalian dapat dilihat dari:

a. Penetapan nilai per pohon.

b. Nominal kredit.

c. Penyaluran kredit secara bertahap.

d. Persepsi petani terhadap kesesuaian dana pengajuan.

e. Suku bunga BI rate.

f. Pengembalian kredit oleh petani. Prinsip tepat penyaluran dan pengembalian sebagaimana dijelaskan pada Tabel 9.

Penentuan nominal PTT diberikan kepada petani berdasarkan jumlah batang pohon yang diagunkan, ukuran diameter, dan jenis pohon. Jumlah kredit yang didapatkan tiap petani adalah $80 \%$ dari perkalian jumlah pohon menurut jenis dan kelas diameternya sesuai dengan standar harga yang telah ditentukan menurut survei harga pasar di kabupaten setempat. Pemberian maksimal $80 \%$ dari BLU dianggap petani sebagai taksiran rendah terhadap nilai pohon agunan. Alasan BLU adalah untuk membantu keuntungan petani dari hasil penjualan kayu di akhir daur atau dari aset lain pada saat pengembalian kredit (pokok dan bunga).

BLU menerapkan aturan bahwa proses penyaluran kredit dilaksanakan secara bertahap. Proses penyaluran uang per termin dengan jarak waktu pencairan satu tahun di kedua kabupaten, dianggap tidak sesuai dengan harapan atau perencanaan petani yang membutuhkan uang cepat dalam

Tabel 9 Pengamatan PTT dengan kriteria prinsip tepat penyaluran dan pengembalian Table 9 Field observation by principal criteria of appropriate disbursement and repayment

\begin{tabular}{|c|c|c|}
\hline \multirow[b]{2}{*}{ Kriteria (Criteria) } & \multicolumn{2}{|c|}{ Pengamatan (Observation) } \\
\hline & $\begin{array}{l}\text { Kabupaten Blora } \\
\text { (Blora Regency) }\end{array}$ & $\begin{array}{l}\text { Kabupaten Wonosobo } \\
\text { (Wonosobo Regency) }\end{array}$ \\
\hline $\begin{array}{l}\text { a. Nilai per pohon agunan } \\
\text { (Value of collateral tree) }\end{array}$ & $\begin{array}{l}\text { Harga standar rata-rata hasil survei } \\
\text { BLU }\end{array}$ & $\begin{array}{l}\text { Harga standar rata-rata hasil survei } \\
\text { BLU }\end{array}$ \\
\hline $\begin{array}{l}\text { b. Nominal kredit (Credit } \\
\text { nominal) }\end{array}$ & Maksimal $80 \%$ dari harga pasar & Maksimal $80 \%$ dari harga pasar \\
\hline $\begin{array}{l}\text { c. Tahapan penyaluran } \\
\text { kredit (Phase of credit } \\
\text { disbursement) }\end{array}$ & $\begin{array}{l}\text { Persentase penyaluran: } \\
\leq \text { Rp10 juta: } 1 \text { tahap (sekaligus) } \\
\text { Rp10-20 juta: } 2 \text { tahap }(50: 50) \text { atau } \\
(70: 30) \\
>\text { Rp20 juta: } 3 \text { tahap }(40: 30: 30)\end{array}$ & $\begin{array}{l}\text { Persentase penyaluran: } \\
\leq \text { Rp20 juta: } 1 \text { tahap (sekaligus) } \\
>\text { Rp20 juta: } 2 \text { tahap }(70: 30)\end{array}$ \\
\hline $\begin{array}{l}\text { d. Persepsi petani terhadap } \\
\text { dana pengajuan (Farmer's } \\
\text { perception of loan) }\end{array}$ & $\begin{array}{l}\text { Sesuai pengajuan: } 60,38 \% \\
\text { Tidak sesuai pengajuan: } 36,62 \%\end{array}$ & $\begin{array}{l}\text { Sesuai pengajuan: } 50,72 \% \\
\text { Tidak sesuai pengajuan: } 42,98 \%\end{array}$ \\
\hline $\begin{array}{l}\text { e. Suku bunga sesuai BI rate } \\
\text { per tahun dan flat (Flat } \\
\text { interest rate) }\end{array}$ & Suku bunga $5,75 \%$ (2013) & $\begin{array}{l}\text { Desa Kalimendong: } 5,75 \%(2013) \\
3 \text { Desa lain: } 7,5 \%(2014)\end{array}$ \\
\hline $\begin{array}{l}\text { f. Pengembalian kredit (Credit } \\
\text { repayment) }\end{array}$ & $\begin{array}{l}\text { Lancar: } 5 \text { orang }(41,67 \%) \\
\text { Tidak lancar: } 7 \text { orang }(58,33 \%)\end{array}$ & $\begin{array}{l}\text { Lancar: } 13 \text { orang }(18,84 \%) \\
\text { Tidak lancar: } 56 \text { orang }(81,16 \%)\end{array}$ \\
\hline
\end{tabular}

Sumber (Source): Data primer dan sekunder 2016, diolah (Primary and secondary data 2016, processed). 
kondisi mendesak. Terlebih, pencairan tahap selanjutnya harus melalui proses monitoring dan evaluasi pohon agunan dengan mempertimbangkan jumlah pohon, penanda pohon, dan kualitas pohon. Hasil monitoring dan evaluasi akan menentukan lolostidaknya untuk mendapatkan persetujuan pencairan tahap selanjutnya.

Pengembalian kredit merupakan salah satu tolak ukur apakah proram PTT ini berhasil atau tidak. Petani Blora dan Wonosobo sudah memahami bahwa pengembalian dilakukan sesuai pencairan kredit (pokok dan bunga) tiap termin setelah jatuh tempo. Pengembalian pinjaman dapat dilakukan pada saat jatuh tempo, mengangsur, atau ketika mendapat punishment dari BLU karena adanya wanprestasi. Wanprestasi adalah ketika petani menebang pohon agunan sebelum jatuh tempo dan tidak melaporkan kepada petugas BLU (PO).

Bagi petani yang sudah melakukan tebangan, wajib mengembalikan PTT karena wanprestasi dan mendapat surat tagihan pembayaran. Dalam jangka waktu setahun setelah pencairan PTT, petani di Wonosobo sudah mendapat surat tagihan pembayaran. Alasan petani Wonosobo belum mengembalikan PTT, antara lain:

a. Tidak semua pohon agunan ditebang.

b. Petani tetap akan mengembalikan kredit sesuai jatuh tempo lima tahun sesuai perjanjian karena menunggu kayu bertumbuh hingga lima tahun lebih menjanjikan dan bernilai dibandingkan ditebang saat ini untuk melunasi kredit.

c. Tidak ada kehadiran PO (petugas lapangan BLU) untuk berkoordinasi saat rencana tebangan karena hama dan penyakit.

Alasan petani di Kabupaten Blora belum mengembalikan pinjaman karena mereka akan membayarnya sesuai waktu kontrak perjanjian.

Berdasarkan gambaran kriteria prinsip
4T, beberapa pelaksanaan PTT sesuai dengan kriteria prinsip tetapi komitmen petani untuk menjaga pohon agunan sampai umur masak tebang belum dapat dilaksanakan (keparalegalan). Itikad, komitmen, dan karakter yang baik dari petani untuk menjaga pohon agunan merupakan prinsip yang sesungguhnya dari PTT. Itikad baik dan karakter yang baik akan menambah keyakinan kreditur terhadap debitur (Guntoro, 2014).

Komitmen pemerintah (KLHK) melalui PTT adalah untuk membantu ekonomi petani dengan tetap memberikan perhatian terhadap lingkungan. Adanya PTT diharapkan pengembangan HR dapat membantu ketersedian bahan baku industri dan masyarakat dapat menerima manfaat jangka panjang dengan nilai ekonomi kayu yang lebih tinggi.

\section{G. Keinginan Melanjutkan Program PTT}

Penilaian pelaksanaan pinjaman dapat juga dilihat dari motivasi petani debitur untuk melanjutkan program PTT. Pengumpulan data dilakukan melalui wawancara motivasi petani yaitu apakah berkeinginan melanjutkan program PTT, tidak, atau raguragu. Motivasi petani terhadap kelanjutan program disajikan pada Tabel 10.

Minat petani untuk melanjutkan program PTT cukup tinggi karena merasakan manfaat dan keuntungan dari program tersebut. Di sisi lain, minat tinggi tersebut berpotensi tidak diikuti dengan komitmen untuk menjaga agunan karena proses dan prosedur yang belum sederhana dan nominal yang diterima belum sesuai harapan. Respon petani menjawab ragu-ragu karena belum dapat memastikan kondisi di masa mendatang sehingga keinginan untuk melanjutkan program tergantung pada kebutuhan, pohon agunan yang dimiliki, taksasi harga kayu terbaru, nominal yang lebih besar, kemudahan persyaratan administrasi, jangka waktu pencairan tidak lama, dan pengembalian sesuai perjanjian 
Tabel 10 Motivasi petani terhadap kelanjutan program PTT

Table 10 Farmer motivation to the continuance PTT programme

\begin{tabular}{|c|c|c|c|c|c|c|c|}
\hline \multirow{2}{*}{$\begin{array}{l}\text { Kabupaten } \\
(\text { Regency) }\end{array}$} & \multirow{2}{*}{$\begin{array}{c}\text { Jumlah petani } \\
\text { (Number of farmer) }\end{array}$} & \multicolumn{2}{|c|}{$\begin{array}{l}\text { Tertarik melanjutkan } \\
\text { (Interested) }\end{array}$} & \multicolumn{2}{|c|}{$\begin{array}{l}\text { Ragu-ragu } \\
(\text { Doubt) }\end{array}$} & \multicolumn{2}{|c|}{$\begin{array}{l}\text { Tidak tertarik } \\
\text { (Not interested) }\end{array}$} \\
\hline & & $\begin{array}{c}\text { Orang } \\
\text { (People) }\end{array}$ & $\%$ & $\begin{array}{c}\text { Orang } \\
\text { (People) }\end{array}$ & $\%$ & $\begin{array}{c}\text { Orang } \\
\text { (People) }\end{array}$ & $\%$ \\
\hline Blora & 53 & 42 & 79,25 & 8 & 15,09 & 3 & 5,66 \\
\hline Wonosobo & 69 & 47 & 68,12 & 4 & 5,80 & 18 & 26,09 \\
\hline Jumlah (Total) & 122 & 107 & 87,70 & 12 & 9,84 & 21 & 17,21 \\
\hline
\end{tabular}

Sumber (Source): Data primer 2016, diolah (Primary data 2016, processed).

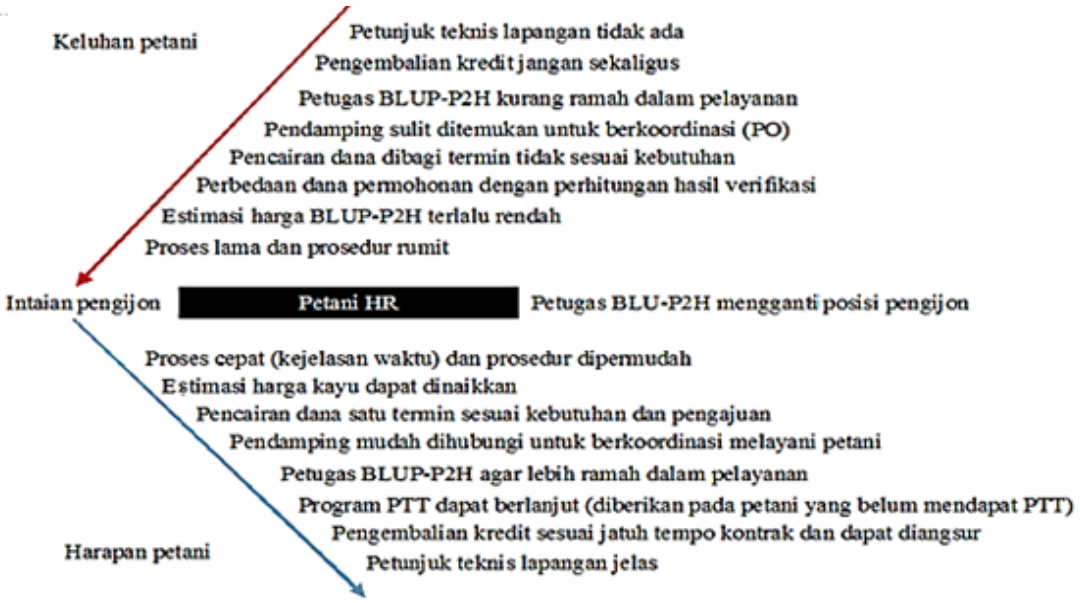

Gambar 3 Harapan petani untuk perbaikan mekanisme program PTT

Picture 3 Expectation of farmers to improving the mechanism of PTT programme.

(jatuh tempo). Respon petani tidak ingin melanjutkan program umumnya disebabkan karena trauma akan proses dan persyaratan yang dirasa berbelit-belit, nominal pinjaman yang tidak sesuai harapan, lamanya waktu pencairan, pengembalian sekaligus dirasa memberatkan, atau bahkan tidak ingin berhutang.

\section{H. Harapan Petani terhadap Perbaikan Mekanisme Pinjaman}

Perbaikan cara kerja dalam melakukan verifikasi sebagaimana diatur dalam Peraturan Kepala Pusat Pembiayaan Pembangunan Hutan Nomor: P.4/P2H/APK/ SET.1/11/2016 hingga proses penyaluran pinjaman menjadi harapan petani. Perbaikan mekanisme penilaian, permohonan pembiayaan, fasilitas dana bergulir, dan skema pinjaman perlu dilakukan untuk meningkatkan minat petani agar tetap mempertahankan pohon agunannya, bahkan dapat menarik perhatian petani lain untuk menjadi debitur.

Keluhan atau ketidakpuasan petani terhadap mekanisme BLU dapat memberi peluang masuknya pengijon atau tengkulak. Harapan petani untuk perbaikan mekanisme program PTT disajikan pada Gambar 3.

\section{KESIMPULAN DAN SARAN}

\section{A. Kesimpulan}

Pemahaman petani debitur terhadap PTT di Kabupaten Blora dan Wonosobo dapat dilihat dari aspek, antara lain: proses pinjaman, ketaatan terhadap kontrak, manfaat pinjaman, dan kepuasan mekanisme 
pinjaman dibandingkan tengkulak. Proses pinjaman tidak sederhana karena persyaratan yang rumit dan waktu pencairan (lag time) yang lama. Pada umumnya petani debitur memahami tidak boleh menebang pohon agunan selama jangka waktu pinjaman dan harus memelihara penanda pohon. Penyimpangan atau keparalegalan dalam "taat asas" terjadi karena masih ada petani yang menebang pohon agunan dan tidak menjaga penanda pohon. Petani merasakan manfaat pinjaman, yaitu: pohon masih terjaga, bunga pinjaman ringan/ lunak, dapat memenuhi kebutuhan seharihari, menambah modal usaha, dan tanaman lain menjadi produktif. Hanya sebagian petani yang menyatakan manfaatnya tidak maksimal. Perbandingan program pinjaman dengan tengkulak dilihat dari: a) realisasi uang pinjaman, yaitu sesuai pengajuan dan tidak sesuai pengajuan, dan b) kepuasan mekanisme PTT oleh BLU. Pada umumnya petani merasa puas dengan mekanisme pinjaman dibanding tengkulak.

Implementasi PTT dilihat berdasarkan ketentuan prinsip 4T, yaitu tepat pelaku, tepat lokasi, tepat kegiatan, dan tepat penyaluran dan pengembalian. Prinsip tepat pelaku pada umumnya sudah baik karena sudah melewati screening administrasi sesuai ketentuan. Petani di Blora sebanyak 53 orang dan di Wonosobo sebanyak 69 orang penerima PTT sudah memenuhi tepat pelaku. Prinsip tepat lokasi pada umumnya sudah baik karena sudah melewati screening bukti-bukti verifikasi lapangan. Ada penyimpangan pada prinsip tepat kegiatan dalam hal komitmen untuk tidak menebang pohon (taat asas) dan menjaga pohon agunan selama masa kontrak. Petani Blora menebang pohon agunan sebanyak $22,65 \%$, sedangkan kebanyakan petani Wonosobo menebang pohon agunan (99\%). Pada tepat pengembalian dan penyaluran masih ada ketidaklancaran dalam mengembalikan pinjaman. Petani Blora yang belum mengembalikan pinjaman sebanyak 7 orang
$(68,33 \%)$ dan petani Wonosobo sebanyak 81 orang $(81 \%)$. PTT belum dapat dilaksanakan dengan baik dan memerlukan perbaikan karena masih ada penyimpangan.

\section{B. Saran}

1. Perlu penyempurnaan Peraturan Kepala Pusat Pembiayaan Pembangunan Hutan Nomor: $\quad$ P.4/P2H/APK/SET.1/11/2016 tentang Pedoman Penilaian Permohonan Pembiayaan Fasilitas Dana Bergulir Untuk Usaha Kehutanan Skema Pinjaman atau prosedur pinjaman PTT, antara lain: terkait tebangan yang sifatnya force majeur seperti serangan hama dan penyakit dan aksi penyelamatannya; SDM pendamping lapangan (PO); dan petunjuk teknis lapangan, khususnya penanda pohon yang mudah dipelihara, tahan lama, dan tidak mudah hilang/ rusak.

2. Diperlukan perbaikan mekanisme birokrasi dan prosedur yang cepat, tepat, dan bermanfaat. Birokrasi yang panjang tidak menjamin komitmen petani untuk patuh dan sesuai prinsip-prinsip pinjaman.

3. Sebagaimana harapan petani, pemerintah dapat membantu memberikan kesempatan sebagai pemasok langsung kayu untuk industri veneer, furniture, dan produk lainnya di sekitar Blora dan Wonosobo sehingga tidak merugikan petani yang selalu bersaing dengan harga dari tengkulak.

\section{UCAPAN TERIMA KASIH (ACKNOWLWDGEMENT)}

Terima kasih kepada Pusat Pendidikan dan Pelatihan SDM Lingkungan Hidup dan Kehutanan, Kepala Pusat Pembiayaan Pembangunan Hutan KLHK, Dinas Kehutanan Kabupaten Blora, Dinas Kehutanan Kabupaten Wonosobo, dan masyarakat desa yang menjadi lokus penelitian di Kabupaten Blora dan Wonosobo. 


\section{DAFTAR PUSTAKA}

Adjognon, S. G., Liverpool-Tasie, L. S. O., \& Reardon, T. A. (2017). Agricultural input credit in Sub-Saharan Africa: Telling myth from facts. Food Policy, 67, 93-105. https:// doi.org/10.1016/j.foodpol.2016.09.014.

Antinori, C., \& Bray, D. B. (2005). Community forest enterprises as entrepreneurial Firms: Economic and institutional perspectives from Mexico. World Development, 33(9 SPEC. ISS.), 1529-1543. https://doi.org/10.1016/j. worlddev.2004.10.011.

Awang, S. A., Santosa, H., Widayanti, W. T., Nugroho, Y., Kustomo., \& Sapardiono. (2001). Gurat Hutan Rakyat di Kapur Selatan (W. Ismoyo (ed.)). DEBUT Press.

Darusman, D. \& Hardjanto. (2006). Tinjauan ekonomi hutan rakyat. Makalah disajikan dalam Seminar Hasil Penelitian Hasil Hutan, Bogor: Fakultas Kehutanan, Institut Pertanian Bogor.

Dharmawan, A. H., Mardiyaningsih, D. I., \& Wianti, N. I. (2012). Analysis of smallholding forest livelihood system: timber certification and its socio-economic impacts (Case studies of three regencies of Central Java Province of Indonesia) (No. 03). In Pro-Formal: Policy and Regulatory Options to Recognise and Better Integrate the Domestic Timber Sector in Tropical Countries. Bogor: Institut Pertanian Bogor.

Dove, M. R. (1995). The theory of social forestry intervention: the state of the art in Asia. Agroforestry Systems, 30(3), 315-340. https:// doi.org/10.1007/BF00705217.

Guntoro, H. (2014). Pelaksanaan Itikad Baik Memory of Understanding dalam Perjanjian Joint Venture Perusahaan Modal Asing. Mimbar Hukum, 26(408), 220-233. https://doi.org/ https://doi.org/10.22146/jmh.16045.

Hardjanto. (2006). Model Struktural Sistem Usaha Kayu Rakyat. Jurnal Manajemen Hutan Tropika, XII(2), 57-68.

Huang, C. H., \& Kronrad, G. D. (2001). The cost of sequestering carbon on private forest lands. Forest Policy and Economics, 2(2001), 133-142. https://doi.org/10.1016/S13899341(01)00046-6.

Irawanti, S., Aneka, S. P., \& Ekawati, S. (2012). Manfaat Ekonomi dan Peluang Pengembangan Hutan Rakyat Sengon di Kabupaten Pati. Jurnal Penelitiaan Sosial dan Ekonomi Kehutanan, 9(3), 126-139.

Kant, P., \& Appanah, S. (2013). Guidelines for Formulating National Forest Financing
Strategies (FAO Region). Food and Agriculture Organization.

Kemenhut. (2012). Statistik Kehutanan Indonesia 2011.

Kementerian Kehutanan. (2014). Statistik Kemnterian Kehutanan Tahun 2013.

KLHK. (2014). Statistik Kementerian Lingkungan Hidup dan Kehutanan 2014. https://doi. org/10.1017/CBO9781107415324.004

Klooster, D., \& Masera, O. (2000). Community forest management in Mexico: Carbon mitigation and biodiversity conservation through rural development. Global Environmental Change, 10(4), 259-272. https://doi.org/10.1016/ S0959-3780(00)00033-9.

Kozak, R. a. (2007). Small and medium forest enterprises: instruments of change in the developing world. Api.Ning.Com. https://doi. org/10.1017/CBO9781107415324.004.

Luan, D. X., \& Bauer, S. (2016). Does credit access affect household income homogeneously across different groups of credit recipients? Evidence from rural Vietnam. Journal of Rural Studies, 47, 186-203. https://doi. org/10.1016/j.jrurstud.2016.08.001.

Mustari, T. (2000). Hutan rakyat sengon: daur dan kelestarian hasil (kasus di Kabupaten Sukabumi, Propinsi Jawa Barat). In D. Suharjito (Ed.), Hutan Rakyat di Jawa: Perannya dalam Perekonomian Desa (pp. 85106). Program Penelitian dan Pengembangan Kehutanan Masyarakat (P3KM) IPB.

Napitu, J. P., Hidayat, A., Basuni, S., \& Sjaf, S. (2017). Mekanisme Akses Pada Hak Kepemilikan Di Kesatuan Pengelolaan Hutan Produksi Meranti, Sumatera Selatan. Jurnal Penelitian Sosial dan Ekonomi Kehutanan, 14(2), 101-118. http://ejournal.forda-mof. org/ejournal-litbang/index.php/JPSE/article/ view/2591/pdf_1.

Nugroho, B, Dermawan, A., \& Putzel, L. (2013). Financing smallholder timber planting in Indonesia : mis- matches between loan scheme attributes and smallholder borrowing characteristics. International Forestry Review, 15(4), 499-508.

Nugroho, Bramasto., Soedomo, S., \& Dermawan, A. (2017). Policy effectiveness of loan for delaying timber harvesting for smallholder private forest in Indonesia. Jurnal Manajemen Hutan Tropika, 23(2), 61-70. https://doi. org/10.7226/jtfm.23.2.61

Nugroho, Bramasto. (2010). Pembagunan kelembagaan pinjaman dana bergulir hutan rakyat. Jurnal Manajemen Hutan Tropika, XVI(3), 118-125. 
Palys, T. (2008). Purposive sampling. In L. M. Given (Ed.), The Sage Encyclopedia of Qualitative Research Methods (Vol. 2, pp. 697-698). Sage Publications, Inc.

Purwanto, R. H., Maryudi, A., Yuwono, T., Permadi, D. B., \& Sanjaya, M. (2015). Potensi Biomasa dan Simpanan Karbon Jenis-jenis Tanaman Berkayu di Hutan Rakyat Desa Nglanggeran, Gunungkidul, Daerah Istimewa Yogyakarta. Jurnal Ilmu Kehutanan, 6(2), 128-141. https://jurnal.ugm.ac.id/jikfkt/article/ view/5778/4688.

Peraturan Kepala Pusat Pembiayaan Pembangunan Hutan Nomor: P.2/P2H-2/2016 Tentang Pedoman Permohonan Pembiayaan Fasilitas Dana Bergulir Untuk Usaha Kehutanan Skema Pinjaman, 1 (2016).

Peraturan Kepala Pusat Pembiayaan Pembangunan Hutan Nomor: P.4/P2H/APK/SET.1/11/2016 Tentang Pedoman Penilaian Permohonan Pembiayaan Fasilitas Dana Bergulir Untuk Usaha Kehutanan Skema Pinjaman, 23 (2016).

Puspitojati, T., Mile, M. Y., Fauziah, E., \& Darusman, D. (2014). Hutan Rakyat: Sumbangsih Masyarakat Pedesaan Untuk Hutan Tanaman (Bahruni (ed.)). PT. Kanisius.

Qureshi, M. I., Saleem, A., Bashir, S., Ruqia, U., Khattak, A. U., Khan, M. G., \& Kundi, F. (2012). Role of micro credit institution of Pakistan for poverty alleviation : A case study of Khushhali Bank of Pakistan. The Journal of Commerce, 5(3), 20-31.

Rohadi, D., Roshetko, J. M., Perdana, A., Blyth, M., Nuryartono, N., Kusumowardani, N., Pramono, A. A., Widyani, N., Fauzi, A., Sasono, J., Sumardamto, P., \& Manalu, P. (2012). Improving economic outcomes for smallholders growing teak in agroforestry in Indonesia (Issue April). https://doi. org/10.1163/157007490X00133.
Sanudin., Awang, S. A., Sadono, R., \& Purwanto, R. H. (2016). The Farmers Perception on Effectiveness of Private Forest Revolving Fund Distribution and Factors Affecting its Repayment: Case in Katibung Subdistrict, South Lampung District, Lampung Province. Jurnal Management Hutan Tropika, 22(1), 47-56. https://doi.org/10.7226/jtfm.22.1.47.

Sanudin, \& Awang, S. A. (2019). Evaluasi Kehutanan Sosial: Tantangan Generasi 3 (Cetakan 1). Kementerian Lingkungan Hidup dan Kehutanan: Direktorat Jenderal Konservasi Sumber Daya Alam dan Ekosistem.

Suprapto, E. (2010). Hutan Rakyat: Aspek produksi, ekologi dan kelembagaan. Arupa, 1-8.

Wibowo, S. A., \& Haryadi, F. T. (2006). Faktor Karakteristik Peternak yang Mempengaruhi Sikap terhadap Program Kredit Sapi Potong di Kelompok Peternak Andiniharjo Kabupaten Sleman Yogyakarta. Media Peternakan, 29(3), 176-186.

Yergin, H., Mercan, M., \& Erol, A. (2015). Assessment of Efficiency and Effectiveness of Micro Credit Application From SocioEconomic and Political Perspectives: The Case of Hakkari. Procedia Economics and Finance, 23 (October 2014), 176-179. https:// doi.org/10.1016/S2212-5671(15)00405-0. 